\title{
Biotechnological production of bioflavors and functional sugars
}

\author{
Produção biotecnológica de bioaromas e açúcares funcionais
}

\author{
Juliano Lemos BICAS ${ }^{1}$, Júnio Cota SILVA², Ana Paula DIONÍSIO², Gláucia Maria PASTORE²*
}

\begin{abstract}
Bioflavors and oligosaccharides are two classes of substances that may be produced biotechnologically through microbial bioprocesses. These compounds have attracted the interest of pharmaceutical and food industries not only due to their technological properties (sweetening/ fiber or flavoring, respectively), but also as a consequence of other functional properties such as, for example, health promoting benefits. The use of agro-industrial residues as substrates in biotechnological processes seems to be a valuable alternative in helping to overcome the high manufacturing costs of industrial fermentations. This manuscript reviews the most important advances in biotechnological production of bioflavors and oligosaccharides. The use of some agro-industrial residues in such processes is also cited and discussed, showing that this is a rising trend in biotechnology.

Keywords: bioflavors; biotransformation; de novo synthesis; functional food; oligosaccharides.
\end{abstract}

\section{Resumo}

Bioaromas e oligossacarídeos são duas classes de substâncias que podem ser produzidas biotecnológicamente por meio de bioprocessos microbiológicos. Estes compostos têm atraído o interesse das indústrias farmacêutica e de alimentos não só devido às suas propriedades tecnológicas (adoçantes/fibras ou aromatizantes, respectivamente), mas também como consequência de outras propriedades funcionais como, por exemplo, benefícios na promoção da saúde. O uso de resíduos agroindustriais como substrato em processos biotecnológicos parece ser uma alternativa valiosa para superar os altos custos de manufatura envolvidos nas fermentações industriais. Este manuscrito faz uma revisão dos mais importantes avanços na produção biotecnológica de bioaromas e oligossacarídeos. O uso de alguns resíduos agroindustriais nestes processos também são citados e discutidos, mostrando que esta é uma tendência crescente na biotecnologia.

Palavras-chave: bioaromas; biotransformação; síntese de novo; alimentos funcionais; oligossacarídeos.

\section{Introduction}

In recent years, it has been considered that food additives should supply not only basic nutritional and technological attributes to the final product. Their desirable properties are natural origin, different technological functions in food and favorable contribution to the promotion of consumer's health and well-being. These characteristics, typical of the socalled functional foods, may be found in bioflavors and some oligosaccharides. Bioflavors, for example, have shown biological activity in vitro and in vivo against certain types of tumor (CROWELL, 1999). Some of them can also be used to induce detoxifying enzymes, for the inhibition of potato sprouting, as an anti-microbial agent, insect repellent, among other uses (DE CARVALHO; DA FONSECA, 2006). Fructooligosaccharide and oligosaccharides, on the other hand, act as dietary fiber since they are non-digestible oligosaccharides (NDO). These NDO are currently considered prebiotics because they are fermented mainly by bifidobacteria and lactic acid bacteria in the colon, reporting beneficial effects for health by increasing the amount of desirable bacteria in the human gut (TOMOMATSU, 1994; ROBERFROID; SLAVIN, 2000; DELZENNE, 2003). Therefore, they have been a substitute for sucrose in some food products.
The importance of functional foods is reflected by their global market, which represents tens of billion dollars and is growing annually at a rate of 7.5\% (SANGEETHA; RAMESH; PRAPULLA, 2005; SLOAN, 2002).

Biotechnology might be broadly defined as any technique that uses living organisms (or parts of them) to make or modify products, to improve plants or animals, or to develop microorganisms for specific uses. Therefore, it is the application of science and engineering, using living organisms or their derived substances, to generate products or to perform functions that can benefit the human condition. In this sense, biotechnological bioprocesses is a subdivision of biotechnology that is responsible for translating the discoveries of life science into practical products, processes, or systems that can serve the needs of society (CBE, 1992). The biotechnological production of food products has been used by human beings since prehistory for the preparation of fermented beverages, breads etc. However, it was only in the last decades of $20^{\text {th }}$ century that the use of this technique was extended to the manufacturing of ingredients, e.g. flavors and oligosaccharides. Since then, the 
industrial adoption of biotechnology has grown constantly in our society, but many bioprocesses are not yet commercially available due to high costs involved.

In parallel, the food, agricultural and forestry industries generate annually millions of tons waste, e.g. bagasses, peels, husks, pulps, aqueous residues and others, many of which raise serious disposal issues and, consequently, considerable costs to various industries. Therefore, an integrated management of these wastes according to the concept "reduce, reuse, and recycle" is constantly being researched (MAKKAR; CAMEOTRA, 2002). One of the alternatives is the possibility of using agro-industrial residues as raw materials in the production of industrially relevant and value-added compounds (ORZUA et al., 2009), with the advantage of providing alternative, abundant, cheaper and readily available substrates to bioprocesses and overcoming environmental problems as a result of their disposal. Industrially, these residues are particularly suited to the field of enzyme and fermentation technology, being especially applicable as substrate for biomass production (PANDEY et al., 2000a).

This paper reviews the latest advances obtained in the field of microbial production of bioflavors and functional oligosaccharides. The possibility of applying biotechnological residues in such processes is also considered.

\section{Bioflavors}

The sensory evaluation of a food product indicates that aroma is one of the most powerful parameters determining the product's quality and acceptance. The most common characteristic of aroma compounds is their volatility (molecular weight usually lower than $400 \mathrm{Da}$ ). These molecules may be hydrocarbons, alcohols, aldehydes, ketones, acids, esters or lactones that are present in low concentrations in the composition of food products.

Basically, there are three methods for obtaining aroma compounds (FRANCO, 2004):

- direct extraction from nature;

- chemical transformation; and

- biotechnological transformations, which include microbial and enzymatic biotransformations, de novo synthesis and genetic engineering.

The production of natural flavors has usually been undertaken by the direct recovery from nature, although many disadvantages are encountered:

- low concentrations of the product of interest, which increases the extraction and purification procedures;

- dependency on seasonal, climatic and political features; and

- possible ecological problems involved with the extraction.

Chemical transformations result in satisfactory yields and good production rates. However, they hardly present adequate regio- and enantio-selectivity to the substrate, resulting in a mixture of products. This results in significant changes in the product's desired aroma. Moreover, the compounds produced chemically are labeled as "artificial" or "nature identical", decreasing their economic interest.

Biotechnological production, on the other hand, is an attractive alternative for the production of flavors, since it occurs at mild conditions, presents high regio- and enantio-selectivity, does not generate toxic wastes and the products obtained may be labeled as "natural". Additionally, there are some compounds that may be produced exclusively via biotechnology. In this sense, biotechnology is an interesting approach for the production of bioflavors, since these compounds are defined as "natural" or “naturally produced" flavors (DEMYTTENAERE, 2001).

As already mentioned, the biotechnological production of aroma compounds may be performed in two basic ways: through de novo synthesis or by biotransformations, both being possible with genetically modified organisms. De novo ("from the new") synthesis refers to the production of complex substances from simple molecules through complex metabolic pathways. Biotransformations, on the other hand, are single reactions catalyzed enzymatically to result in a product structurally similar to the substrate molecule. The main biotechnological processes employed for the production of bioflavors by means of de novo synthesis and biotransformations will be discussed below.

\section{Production of bioflavors by de novo synthesis}

Volatile organic chemicals are the sensory principles of many products and promote their acceptance and market success (BERGER, 2009). Thus, flavor and aroma synthesis by biotechnological processes nowadays plays an increasing role in the food, feed, cosmetic, chemical and pharmaceutical industries. Apart from plant cell and tissue culture techniques, a directly viable alternative route for flavor synthesis is based on microbial processes, i.e. fermentation (de novo synthesis) and bioconversion of appropriate precursor compounds (JANSSENS et al., 1992; MEDEIROS et al., 2000). In this paper, the most important groups of flavors are represented below.

Terpenes are the most abundant group in nature responsible for the characteristic odors of essential oils, and are a preferable substrate for bioconversions studies (JANSSENS et al., 1992). In studies involving de novo synthesis, terpenes are present only in a few works. Most of the terpene-producing microorganisms are fungi, and a typical example is the genus Ceratocystis which produces aroma compounds. The production of several aroma compounds (citronellol, geraniol, linalool, nerol, a-terpineol and others) using Ceratocystis strains was verified in literature (BLUEMKE et al., 2001; COLLINS et al., 1977; LANZA et al., 1976; HUBBALL et al., 1978). Several studies using another species (i.e. Ascoidea hylecoeti, Cronartium fusiforme, Phellinus sp., Pleurotus euosmus) also produced terpene compounds (FRANCKE et al., 1978; DRAWERT et al., 1983; LASETER; WEETE; WALKINSHAW, 1973; JANSSENS et al., 1992). The same terpene-derived compounds were reported in countless pieces of research using microbiological bioconversion, producing aroma compounds with an added value (see topic Production of bioflavors by biotransformation). 
Production of volatile fruity aromas occurs during the growth of several microbial species in different culture media (PASTORE; PARK; MIN, 1994). Esters are the most important group involved in the fruity flavor and they are employed in fruit-flavored products and dairy products (GATFIELD, 1988; LONGO et al. 2006). Some research can be found in the literature using different microorganisms for de novo synthesis to produce ester compounds. The moulds Saccharomyces sp., Hansenula sp. and Candida utilis could produce ethyl acetate in a medium containing ethanol (ARMSTRONG et al., 1984). Ethyl hexanoate is another important compound, with a fruity characteristic note (PASTORE; PARK; MIN, 1995; YAMAUCHI; HASUO; AMACHI, 1989; YAMAUCHI, 1991; YOSHIZAWA et al., 1988). The formation of other microbial esters was recently described in a review (PARK et al., 2009).

In appropriate concentration, unsaturated alcohols have an important aroma function in the product. BERGER (2009) reported that these alcohols may be produced biotechnologically to generate commercial natural aroma chemicals. The production of some alcohols, e.g. 1-octen-3-ol, is well reported in different studies (ASSAF et al., 1997; PASTORE; PARK; MIN, 1995; YAMAUCHI; HASUO; AMACHI, 1989; YAMAUCHI et al., 1991; YOSHIZAWA et al., 1988).

Lactones (cyclic ketones) are associated with odor impressions such as fruit, coconut-like, sweet or nutty notes (JANSSENS et al., 1992; MARQUES et al., 1999). Lactones may be produced by chemical synthesis, but the advantages associated with using bio-production encouraged the production by fermentation using fungus and yeast strains. Sporobolomyces odorus is a yeast which produces de novo up to $1.6 \mathrm{mg} . \mathrm{L}^{-1}$ of 4 -decalactone, resulting in an intense peach odor. A soil fungus, Trichoderma viride, generates a strong coconut aroma, with a production of $170 \mathrm{mg} . \mathrm{L}^{-1}$ of 6-penthyl-2-pyrone, the character impact compound (WELSH; MURRAY; WILLIAMS, 1989).

Pirazines are heterocyclic nitrogen-compounds which contribute significantly to the flavor of many foods. They confer the typical aroma of heated foodstuffs, normally formed through the Maillard reaction. However, a few microorganisms are also able to produce pyrazines, i.e. Bacillus subtilis (KOSUGE; KAMIYA, 1962) and Corynebacterium glutamicum (DEMAIN et al., 1967). The last one was able to produce 3 g.L. $\mathrm{L}^{-1}$ of tetramethypyrazine in a 5-day fermentation.

Currently, advances in industrial biotechnology offer potential opportunities for economic utilization of agroindustrial residues. Considering the present importance of using an economic sources of nutrients, Berger (2009) suggested the use of non-conventional media in the biotechnology of flavors. Thus, many research groups have developed procedures that involve the use of residues, and this is the focus in this review.

Solid state fermentation (SSF) is an important technology for value-addition, and utilization of these products and their residues as these could be economically useful for the production of flavor and aroma compounds, so that this represents a promising strategy (SINGHANIA et al., 2009; PANDEY, 2003; PANDEY et al., 2000c; PANDEY et al. 2000b, WANG; YANG, 2007; HÖLKER; LENZ, 2005). This technique is defined as any fermentation process performed on a non-soluble material that acts both as physical support and as source of nutrients in the absence of free flowing liquid (WANG; YOUNG, 2007).

Citric pulps are a solid waste derived from the citric juice industry and studies have demonstrated that it is an adequate substrate for aroma production by C. fimbriata, opening new promising perspectives for this process. The microorganism was used to produce fruity aroma compounds in citric pulp medium. After $24 \mathrm{~h}, \mathrm{a} \sim 100 \mu \mathrm{mol} . \mathrm{L}^{-1} \cdot \mathrm{g}^{-1}$ of total volatiles (represented by ethyl acetate and isoamyl acetate) were detected when the citric pulp was supplemented with $50 \%$ of soy bran, $25 \%$ of sugarcane molasses, and mineral saline solution, containing $\mathrm{KH}_{2} \mathrm{PO}_{4}$, $\mathrm{CaCl}_{2}$ and $\mathrm{MgSO}_{4}$ (ROSSI et al., 2009).

Coffee pulp and husk are coffee-derived residues and offer potential opportunities in industrial biotechnology, including flavor production (PANDEY et al., 2000c). SOARES et al. (2000) studied a fruity flavor production by C. fimbriata grown on steam-treated coffee husk supplemented with glucose. The results showed strong pineapple and banana aroma compounds formed in the fermentation, using different concentrations of glucose (20-46\%). When leucine was enhanced in the medium, the total volatiles were evidenced, especially for ethyl acetate and isoamyl acetate, resulting in a strong banana odor. Other aldehydes, alcohols and esters were also identified in the headspace of the cultures.

Pandey et al. (2000d) considered sugarcane bagasse to be an ideal substrate for microbial processes to produce value-added products due to its abundant availability. This residue is the major by-product of the sugar cane industry and contains about $50 \%$ cellulose, $25 \%$ hemicellulose and $25 \%$ lignin. Christen et al. (1997) reported that $C$. frimbriata was able to produce fruity aroma using sugar cane bagasse supplemented with a synthetic medium containing glucose, and when the medium was supplemented with leucine or valine, a strong banana aroma was evidenced. Similar results were obtained when other agroindustrial residues (wheat bran and cassava bagasse) presented a leucine or valine supplementation. Actually, this C. fimbriata strain is one of the most extensively studied microorganisms for the de novo synthesis of fruity flavor compounds and it has been tested in a variety of other agro-industrial residues, supplemented or not.

Cassava bagasse, a fibrous material of the cassava-processing industry, contains about 30 to $50 \%$ of starch on dry weight basis. Due to its rich organic nature and low ash content, it can serve as an ideal substrate for microbial processes for the production of value-added products (PANDEY et al., 2000a). Bramorski et al. (1998b), using the C. fimbriata strain, compared to fruity aroma production in solid-state cultures from four agro-industrial wastes: cassava bagasse, apple pomace, amaranth and soybean. Cassava bagasse was used in combination with soybean or apple pomace, and all the media supported fungal growth. A strong fruity aroma was evidenced in media containing cassava bagasse with apple pomace or soybean. The major components identified were esters and alcohols, and minor quantities of acid, aldehyde and ketones were found too. When Rhizopus strains were used with the same agro-industrial residues, the production of total volatile compounds increased more than three times, reaching 
$\sim 280 \mu$ mol ethanol eq. per $\mathrm{L}$, when an amaranth medium added with mineral salt solution was used. Finally, the Rhizopus oryzae ATCC 34612 strain was chosen as the most suitable strain in this procedure (CHRISTEN et al., 2000).

Rhizopus oryzae was tested to produce volatile compounds using cassava bagasse, soybean meal and amaranth grain as substrates, and an alcohol (ethanol) was the major volatile compound, constituting more than $80 \%$ of the total. Lower concentrations of aldehydes, esters and other alcohols were identified (BRAMORSKI et al., 1998a).

Optimization studies for the production of aroma compounds were conducted using the Kluyveromyces marxianus microorganism. The production of fruity aroma compounds (principally alcohols, aldehydes and esters) obtained from yeast culture was feasible when using cassava bagasse and giant palm bran (Opuntia ficus indica) as substrates. When cassava bagasse was supplemented with $10 \%$ of glucose, the production of esters (ethyl acetate), mainly responsible for the fruity aroma, was favored (MEDEIROS et al., 2000). Finally, the use of cassava wastewater, a liquid residue from the cassava industry, has also been reported for the production of aroma compounds by the cyanide-resistant Geotrichum fragans. After 72 hours of fermentation some alcohols, esters and acid were found to accumulate (DAMASCENO et al., 2003).

\section{Production of bioflavors by biotransformation}

Biotransformations can be briefly described as chemical reactions catalyzed by microorganisms or enzyme systems and are usually carried out with growing cultures, previously grown cells, immobilized cells, purified enzymes, or multiphase systems (BICAS et al., 2009). This biotechnological approach plays a key role in the area of foodstuffs, chiral drugs industry, vitamins, specialty chemicals, and animal feed stock (DOBLE; KRUTHIVENTI; GAIKAR, 2004). In the field of flavor production, biotransformations have increasingly been investigated in recent years and appear to be one of the most promising manufacturing techniques for the future (BICAS et al., 2009).

$R-(+)$-limonene is one of the most studied precursors in biotransformation experiments for the production of bioflavors. Its chemical structure, similar to valuable oxygenated flavor compounds (carveol, carvone, perillyl alcohol, terpineols etc), presents one chiral center and ten carbons, six being cycled, which classifies it as a monocyclic monoterpene. Different microorganisms are able to degrade this molecule for the production of flavor compounds. The main metabolic pathways through which these biotransformations are possible have been reviewed recently (MARÓSTICA Jr. et al., 2007a; BICAS et al., $2008 \mathrm{~b}$ ). The most recent advances in the field were obtained for the biotransformation of limonene in a-terpineol production. This compound is a monoterpene alcohol widely applied in cosmetics, food and household products and flavor preparations (BAUER et al., 2001). One of the first processes for the conversion of limonene to $\alpha$-terpineol was performed with a Cladosporium sp. and the production obtained reached almost 1.0 g. $\mathrm{L}^{-1}$ (KRAIDMAN et al., 1969). Years later many researchers have described the use of Penicillium digitatum for this bioprocess (DEMYTTENAERE; VAN BELLEGHEM; DE KIMPE, 2001; ADAMS et al., 2003). The use of organic co-solvents (TAN; DAY, 1998b), immobilized biomass (TAN; DAY, 1998a) and a closed gas loop bioreactor (PESCHECK et al., 2009) have been considered in some cases, but a significant production was only reached through sequential substrate addition (TAN et al., 1998c). More recently, Fusatium oxysporum has also been applied to the production of a-terpineol from limonene. The first description of such a process indicated a production lower than 500 mg.L.-1 (MARÓSTICA Jr.; PASTORE, 2007b), which was further optimized by means of statistical methods to result in a product concentration of $2.4 \mathrm{~g} . \mathrm{L}^{-1}$ after 72 hours of process (BICAS et al., 2008a). Subsequently, this biotransformation was characterized and the $a$-terpineol concentration was recalculated using a more reliable technique, which resulted in a new productivity value, close to $4 \mathrm{~g} . \mathrm{L}^{-1}$ after 48 hours (BICAS et al., 2010). The last study also indicated an interesting possibility of using the F. oxysporum strain to co-produce, in the same process, alkaline lipase. The biotransformation of limonene for $\alpha$-terpineol has also been described for bacterial strains. Pseudomonas gladioli, for example, could produce up to 1.0 g.L. $\mathrm{L}^{-1}$ of $a$-terpineol (CADWALLADER et al., 1989) and the enzyme responsible for this biotransformation, called a-terpineol dehydratase, was isolated and characterized in the following study (CADWALLADER et al., 1992). The use of genetic engineering tools has also been considered for this biotransformation, when a recombinant $E$. coli could express a-terpineol dehydratase from a Bacillus sp. strain (SAVITHIRY; CHEONG; ORIEL, 1997). However, the most interesting report, on what is perhaps the most viable process from an industrial and economical point of view, was performed using Sphingobium sp. (formerly identified as $P$. fluorescens) in a biphasic system. When sunflower oil was used as organic phase, $\boldsymbol{\alpha}$-terpineol production could reach up to $120-130$ g.L $\mathrm{L}^{-1}$ in less than four days under non-optimized conditions (BICAS et al., 2009). This is, as far as the authors know, the highest bioflavor production ever described for a microbial biotransformation.

One interesting approach in terpene biotransformation processes is the possibility of replacing terpene standards with essential oils as substrate. The main examples are turpentine oil, a by-product from the paper and cellulose industry rich in $\alpha$ - and $\beta$-pinenes, and orange peel oil, a by-product from citrus industry rich in $R-(+)$-limonene (90-95\%), which were used for screening bioflavor-producing fungi. The biotransformation of $R$-(+)-limonene, $\alpha$ - and $\beta$ - pinenes from these oils resulted in $\alpha$-terpineol and perillyl alcohol, verbenol and verbenone, respectively, as the main products. The concentrations, however, remained lower than $100 \mathrm{mg} \cdot \mathrm{L}^{-1}$ even when terpene standards were used (MARÓSTICA et al., 2007). In another study, a higher $R-(+)$ - $\alpha$-terpineol production could be obtained from orange peel oil using F. oxysporum, as already mentioned above (MARÓSTICA; PASTORE, 2007b).

Vanillin, one of the main aroma compound applied worldwide, may also be produced in high yields through microbial biotransformations (DAUGSCH; PASTORE, 2005; WALTON et al., 2000). This compound, extensively used in the food and pharmaceutical industries, has been historically 
obtained by extraction from the fermented pods of Vanilla orchids. Today, synthetic vanillin produced from kraft lignin, with a price $\sim 100$ times lower, dominates the market. The higher yield already obtained for biotechnologically-produced natural vanillin refers to patent processes: the bioconversion of ferulic acid into vanillin by strains of Amycolatopsis sp. or Streptomyces setonii in a $10 \mathrm{~L}$ bioreactor, with a final production of, respectively, 11.5 g.L. $\mathrm{L}^{-1}$ (conversion rate of $77.8 \%$ ) after $32 \mathrm{~h}$ (RABENHORST; HOPP, 2000) or 13.9 g.L. $\mathrm{L}^{-1}$ (yield of 75\%) after 17 hours of the substrate feed (MUHEIM et al., 2001). In fact, the microbial transformation of ferulic acid is recognized as the most attractive and promising alternative source of natural vanillin.

The use of agro-residues as substrates in bioprocesses has also been extensively evaluated for the production of flavors by biotransformation. As already stated elsewhere, this strategy seems to be a rising trend to overcome high manufacturing costs involved in microbial production of bioflavors (BICAS et al., 2009).

Ferulic acid, for example, the precursor of vanillin in biotransformation processes, can be obtained from lignincontaining agricultural residues. Some studies have investigated various agro-industrial by-products as a source of ferulic acid, the main ones being cereal bran or sugar-beet pulp (0.5-1.0 g ferulic acid per $100 \mathrm{~g}$ ) (THIBAULT et al., 1998). Autoclaved maize bran was used as a crude source of ferulic acid. The results revealed a $500-600 \mathrm{mg} . \mathrm{L}^{-1}$ vanillin production after seven days, which could be increased by the use of XAD- 2 resin (LESAGE-MEESSEN et al., 2002). Rice bran oil could also serve as a ferulic acid source for bioconversion in a $25 \mathrm{~L}$ bioreactor, resulting in a production of 1.1 g.L. $\mathrm{L}^{-1}$ of vanillin after 54 hours in a molar yield close to $61 \%$ (ZHENG et al., 2007). Engineered Escherichia coli (strain JM109/pBB1), containing the genes for feruloyl-SCoA synthetase and feruloyl-SCoA hydratase/aldolase from Pseudomonas fluorescens BF13, has also been used to produce vanillin from wheat bran and corn cob hydrolysates (DI GIOIA et al., 2007; TORRES et al., 2009). The maximum vanillin concentration was relatively low $\left(\sim 240 \mathrm{mg} . \mathrm{L}^{-1}\right)$ when compared to the traditional processes (TORRES et al., 2009), but this is another practical example of genetically modified microorganisms applied to biotransformation processes, an increasing trend in biotechnology.

The use of cassava wastewater, a residue from cassava flour processing, for bioflavor production has also been considered to reduce the manufacturing costs. This agro-industrial residue is rich in sugars $\left(\sim 40\right.$ g. $\left.\mathrm{L}^{-1}\right)$, nitrogen $\left(\sim 2\right.$ g. $\left.\mathrm{L}^{-1}\right)$ and a variety of minerals (K, Mg, P, Ca, S, Fe, Zn, Mn, Cu) and therefore it has been considered very attractive for the growth of many microorganisms (MARÓSTICA; PASTORE, 2007a). The first description of bioflavor production through biotransformation processes using cassava wastewater for biomass production was reported for a Penicillium sp strain. When transferred to a fresh mineral medium with citronellol as sole carbon source, this microorganism produced a mixture of cis- and trans-rose oxides in a total concentration of $\sim 100 \mathrm{mg} . \mathrm{L}^{-1}$ (MARÓSTICA; PASTORE, 2006). Using a similar technique, Fusarium oxysporum, Aspergillus sp. or Penicillium sp. grown in cassava wastewater could biotransform $R-(+)$-limonene to produce $R$-(+)-a-terpineol (MARÓSTICA; PASTORE, 2007b). In both cases, cassava wastewater was suitable for biomass production, but the use of mineral media during the biotransformation was recommended to increase yields (MARÓSTICA; PASTORE, 2006; MARÓSTICA and PASTORE, 2007b).

\section{Oligosaccharides}

Fructooligosaccharides and galactooligosaccharides are the most studied oligosaccharides and are widely applied commercially. However, other oligosaccharides have also been described in the literature. Xylooligosaccharides (XOS), for example, may be produced from hemicellulose of lignocellulosic material wastes, such as wheat bran (MAALEJ-ACHOURI et al., 2009). Chitooligosaccharides (COS) is another class of NDO that have been produced mainly from enzymatic hydrolysis of chitin, whose main sources are crab and shrimp offal (KIM; RAJAPAKSE, 2005). This paper will focus on the most recent advances in the biotechnological production of FOS and GOS.

\section{Fructooligosaccharides (FOS)}

FOS are found as natural components of different elements in the human diet, such as vegetables, fruits and honey; however, the amount of these saccharides is small in these foods and varies with seasonal conditions (HARTEMINK et al., 1997; YUN, 1996). FOS are fructose oligomers, represented mainly by 1-kestose $\left(\mathrm{GF}_{2}\right)$, nystose $\left(\mathrm{GF}_{3}\right)$ and fructofuranosyl nystose $\left(\mathrm{GF}_{4}\right)$. Fructosyl $(\mathrm{F})$ units are bound to one another and to sucrose (GF) via beta glycosidic bonds $(2 \rightarrow 1)$, which differentiates them from other oligosaccharides (YUN, 1996). The human organism does not have enzymes capable of metabolizing FOS; however, these can be fermented by diverse bifidobacteria that colonize the intestine, which allows the number of these cells to increase (MOLIS et al., 1996). This alteration can give rise to physiological responses, such as blood pressure reduction in hypertensive people, alteration of fatty acid metabolism, reduction in carbohydrate and lipid absorption, normalization of blood pressure and serum lipids, in addition to improving the metabolism of diabetic individuals (YAMASHITA; KAWAI; ITAKAMURA, 1984; SPIEGEL; ROSE; KARABELL, 1994; HARTEMINK, 1997; KAUFHOLD; HAMMON; BLUM, 2000).

FOS obtained biotechnologically consist of both linear and branched chains, with a degree of polymerization (DP) ranging from 1 and 5 of fructosyl units (HARTEMINK et al., 1997; LIM et al., 2007). The synthesis of these compounds by microorganisms occurs by means of specific enzymes, which convert sucrose into oligosaccharides in the presence of high concentrations of the substrate. Some authors refer to these enzymes as fructofuranosidases (E.C.3.2.1.26) and others as fructosyltransferases (E.C.2.4.1.9), even those originated from the same microorganism, such as Aspergillus niger. However, the two types of microbial enzymes, the hydrolases (glycosidases, EC 3.2.) and the transferases (glycosyltransferase, EC 2.4.), may, theoretically, synthesize oligosaccharides (MONSAN; PAUL, 1995; YUN, 1996). 
Several enzymes with a transfructosylation activity have been identified and characterized in different microorganisms, such as Glucanocetobacter diazotrophicus (HERNANDEZ et al., 1995; MARTÍNEZ-FLEITES et al., 2005), Lactobacillus reuteri (VAN HIJUM; SZALOWSKA; VAN DER MAAREL, 2004; OZIMEK; KRALJ; VAN DER MAAREL, 2006), Pseudomonas syringae pv. phaseolicola (HETTWER; GROSS; RUDOLPH, 1995), Streptococcus salivarius (SONG; JACQUES, 1999), Bacillus subtilis (CHAMBERT et al., 1974; CHAMBERT; GONZY-TRÉBOUL, 1976), Klyveromyces marxianus (SANTOS; MAUGERI, 2007), Aspergillus aculeatus (GHAZI et al., 2006), Aspergillus niger (PARK; ALMEIDA, 1991), Aspergillus oryzae (SANGEETHA; RAMESH; PRAPULLA, 2005a), Aspergillus japonicus (DORTA et al., 2006; MUSSATO et al., 2009), Penicillium citrinum (HAYASHI; YOSHIYAMA; FUJII, 2000, LIM et al., 2007). Table 1 summarizes the most important parameters and yields from a typical reaction of FOS synthesis.

The production of the enzyme fructosyltransferase can be carried out by solid state fermentation (SSF), using various agricultural by-products such as cereal bran, corn products, sugarcane bagasse, cassava bagasse (tippi) and by-products of coffee and tea processing. The process to produce FTase has been investigated among cereal brans, and results suggest that rice and wheat bran are good substrates for FTase production by
Aspergillus oryzae CFR 202. In addition, corn germ supported maximum FTase production among the various corn products used, whereas among the by-products of coffee and tea processing used, spent coffee and spent tea were good substrates, with supplementation of yeast extract. Maximum FOS production was obtained with FTase after 8 hours of reaction starting from $60 \% \mathrm{w} / \mathrm{v}$ sucrose (SANGEETHA; RAMESH; PRAPULLA, 2004b). A patent application described a method to produce large amounts of the enzyme $\beta$-fructofuranosidase by Aspergillus niger using preferentially wheat bran as substrate. The maximum yield was around $60 \% \mathrm{w} / \mathrm{w}$ of FOS and the results suggested that this is a useful process to be applied on an industrial scale (PARK; PASTORE, 2006).

It was clearly demonstrated that molasses are good nutrient sources to be used as culture medium. Thus, in addition to their use in enzyme production, these residues may also be suitable in the direct production of oligosaccharides by microorganisms (GHAZI et al., 2006; SHIN et al., 2004). Sugar syrup and molasses from beet processing, containing 620 and $570 \mathrm{mg} \cdot \mathrm{mL}^{-1}$ sucrose, respectively, were assayed as low-cost and available substrates for the enzymatic synthesis of FOS. The FOS production increased when lowering the initial $\mathrm{pH}$ value of syrup (7.5) and molasses (8.9) to 5.5. Using approximately $10 \mathrm{U}$ transfructosylating activity per g sucrose, the FOS concentration reached a maximum of $388 \mathrm{mg} \cdot \mathrm{mL}^{-1}$ after 30 hours using syrup

Table 1. Typical features of FOS Synthesis by FTase from different microbial strains.

\begin{tabular}{|c|c|c|c|c|}
\hline Microorganism & Enzyme & Optimal conditions & $\mathrm{Y}_{\mathrm{FOS}}^{*}$ & References \\
\hline Acetobacter diazotrophicus & $\begin{array}{c}\text { Levansucrase } \\
\text { (E.C. 2.4.1.10) - Free enzyme }\end{array}$ & $\begin{array}{c}40^{\circ} \mathrm{C}-\mathrm{pH} 5.5-18 \text { hours - } \\
200 \mathrm{rpm}-\text { sucrose } 60 \%\end{array}$ & $\mathrm{Y}_{\mathrm{FOS}}: 50 \%$ & $\begin{array}{l}\text { Támbara, Hormaza, } \\
\text { Pérez (1999) }\end{array}$ \\
\hline Klyveromyces marcianus & $\begin{array}{c}\text { Inulinase - } \\
\text { Immobilized enzyme }\end{array}$ & $\begin{array}{c}50{ }^{\circ} \mathrm{C}-\mathrm{pH} 6.0-4 \text { hours }- \\
\text { sucrose } 45 \%\end{array}$ & $\mathrm{Y}_{\mathrm{FOS}}: 10 \%$ & $\begin{array}{c}\text { Santos and } \\
\text { Maugeri (2007) }\end{array}$ \\
\hline Penicillium citrinum & $\begin{array}{l}\text { Neo-fructosyltransferase - } \\
\text { Mycelia and co-immobilized enzyme }\end{array}$ & $\begin{array}{c}50{ }^{\circ} \mathrm{C}-\mathrm{pH} 6.0-48 \text { hours - } \\
100 \mathrm{rpm}-\text { sucrose } 60 \%\end{array}$ & $\mathrm{Y}_{\mathrm{FOS}}: 18 \%$ & Lim et al. (2007) \\
\hline Aspergillus sp. & $\begin{array}{l}\beta \text {-fructofuranosidase } \\
\text { (E.C. } 3.2 .1 .26) \text { - Free enzyme }\end{array}$ & $\begin{array}{c}40{ }^{\circ} \mathrm{C}-\mathrm{pH} 5.5-6 \text { hours - } \\
\text { sucrose } 61.5 \%\end{array}$ & $\mathrm{Y}_{\mathrm{FOS}}: 61 \%$ & Fernández et al. (2004) \\
\hline Aspergillus oryzae & $\begin{array}{l}\text { Fructosyltransferase } \\
\text { (E.C. } 2.1 .4 .9 .) \text { - Free enzyme }\end{array}$ & $\begin{array}{c}55^{\circ} \mathrm{C}-\mathrm{pH} 5.5-12 \text { hours - } \\
\text { sucrose } 55 \%\end{array}$ & $\mathrm{Y}_{\mathrm{FOS}}: 54 \%$ & $\begin{array}{l}\text { Sangeetha, Ramesh, } \\
\text { Prapulla (2004b) }\end{array}$ \\
\hline Aspergillus niger & $\begin{array}{l}\beta \text {-fructofuranosidase } \\
\text { (E.C. } 3.2 .1 .26) \text { - Free enzyme }\end{array}$ & $\begin{array}{c}40-65^{\circ} \mathrm{C}-\mathrm{pH} 6.0-8.5- \\
\text { sucrose } 40-70 \%\end{array}$ & $\mathrm{Y}_{\mathrm{FOS}}: 60 \%$ & $\begin{array}{c}\text { Park and } \\
\text { Pastore (2006) }\end{array}$ \\
\hline Aspergillus japonicus & $\begin{array}{c}\beta \text {-fructofuranosidase } \\
\text { (E.C. 3.2.1.26) - Immobilized mycelia }\end{array}$ & $\begin{array}{c}55^{\circ} \mathrm{C}-\mathrm{pH} 5.5-4 \text { hours }- \\
\text { sucrose } 65 \%\end{array}$ & $\mathrm{Y}_{\mathrm{FOS}}: 61 \%$ & Cruz et al. (1998) \\
\hline Aspergillus japonicus & $\begin{array}{c}\beta \text {-fructofuranosidase } \\
\text { (E.C. 3.2.1.26) - Free enzyme }\end{array}$ & $\begin{array}{c}37^{\circ} \mathrm{C}-\mathrm{pH} 5.5-8.5 \text { hours - } \\
200 \mathrm{rpm}-\text { sucrose } 30 \%\end{array}$ & $\mathrm{Y}_{\mathrm{FOS}}: 93 \%$ & Sheu et al. (1998) \\
\hline
\end{tabular}

${ }^{\star}$ Yield of FOS $\left(\mathrm{Y}_{\mathrm{FOS}}\right)$ is defined as the ratio between final concentration of FOS $\left(\mathrm{g} . \mathrm{L}^{-1}\right)$ divided by start concentration of sucrose $\left(\mathrm{g} . \mathrm{L}^{-1}\right)(\times 100)$. 
and 235 mg.mL $\mathrm{mL}^{-1}$ after 65 hours with molasses. These values corresponded to approximately 56 and 49\% w/w, respectively, of the total carbohydrates amount in the mixture (GHAZI et al., 2006). The higher FOS yields reported are around 50-60\% w/w (PARK; PASTORE, 2006; SANGEETHA; RAMESH; PRAPULLA, 2004a; CRUZetal., 1998). Shin etal. (2004) evaluated the growth of three different strains of Aureobasidium pullulans in batch cultures to compare their abilities to produce FOS. Using A. pullulans cells cultivated at $55^{\circ} \mathrm{C}$ and $\mathrm{pH} 5.5,166$ g. $\mathrm{L}^{-1}$ of FOS was produced after 24 hours from 360 g.L $\mathrm{L}^{-1}$ sugar molasses (sucrose equivalent). Therefore, the higher FOS yields achieved by using agro-industrial wastes (56 and 49\% $\mathrm{w} / \mathrm{w}$ ) indicate that these are potential substrates to be applied in industrial synthesis of oligosaccharides, although extensive studies on scale-up processes are needed.

\section{Galactooligosaccharides (GOS)}

GOS are non-digestible, short-chain polysaccharides (DP 3-6) known to promote and sustain the growth of beneficial bacteria, especially Bifidobacterium, within the colon (TOMOMATSU, 1994). GOS are considered as prebiotics and important functional food ingredients linked to numerous health benefits, including reduced colon cancer risk and enhanced immunity (CRITTENDEN, 1999). These characteristics confer a high commercial value to GOS in the United States and global markets. These oligosaccharides may be added to a variety of products, including breads, fermented dairy foods, and beverages (SAKO; MATSUMOTO; TANAKA, 1999). GOS could be synthesized from lactose by a special enzyme called $\beta$-galactosidase (EC 3.2.1.23). $\beta$-Galactosidases, present in a wide variety of sources including plants, animals and microorganisms, are known to catalyze transgalactosylation as well as hydrolysis reactions to produce oligosaccharides (PRENOSIL et al., 1987). The hydrolysis of lactose occurs predominantly at low lactose concentrations, while oligosaccharide production by the transgalactosidase reaction increases with rising concentrations of lactose. The process is complex and involves a multitude of sequential reactions with many intermediate products. During the reaction, sugars other than monosaccharides, glucose and galactose, are also formed. The galactooligosaccharides formed by transgalactosylation are di- and higher saccharides and contain one or more galactosides linked mainly by $\beta$ 1-6 (6'-GOS) and even $\beta$ 1-4 (4'-GOS) bonds (MATSUMOTO; KOBAYASHI; TAMURA, 1989; PRENOSIL; STUCKER; BOURNE, 1987; CUMMINGS et al., 1997).

The reaction of GOS formation could be carried out by different means, such as free or immobilized enzymes or even whole cells. Table 2 summarizes the most relevant reports on GOS synthesis.

The production of the enzyme $\beta$-galactosidase has been studied in some SSF processes which employ agricultural byproducts such as cereal bran and husk as substrates for the mold growth. Wheat bran and rice husk are the most common substrates applied in these SSF processes and they support the maximum growth and $\beta$-galactosidase production by $A$. oryzae (NIZAMIDDIN et al., 2008; SHEU et al., 1998). The fungal culture utilizes several carbon sources for $\beta$-galactosidase induction. Glucose serves as the best carbon source, followed by lactose, maltose and sucrose. Among the various nitrogen sources, sodium nitrate appears to be the best. A recent report showed that the maximum amount of $\beta$-galactosidase activity and protein content could be obtained when SSF is carried out using wheat bran and rice husk in an 1:1 ratio, having an initial moisture of $90 \%$, initial $\mathrm{pH} 5.0$ and supplemented with $(12.5 \%, \mathrm{w} / \mathrm{w})$ glucose and $1 \% \mathrm{w} / \mathrm{w}$ sodium nitrate at $30{ }^{\circ} \mathrm{C}$ for 7 days using $10^{8}$ spores of $A$. oryzae as inoculum size (NIZAMIDDIN et al., 2008).

In recent years, whey lactose has been produced excessively, due to the high production of cheese and whey protein concentrate coupled with low demand and limited applications for lactose. Lactose is the main component of the different types of whey (sweet, acid, ultra-filtrated whey permeate) and it has been found that, during the enzymic hydrolysis of lactose, in addition to the main hydrolysis products (glucose and galactose), considerable amounts of oligosaccharides (GOS) are

Table 2. Typical features of GOS Synthesis by $\beta$-galactosidase (EC 3.2.1.23) from different microbial strains.

\begin{tabular}{|c|c|c|c|c|}
\hline Microorganism & Enzyme & Optimal conditions & $\mathrm{Y}_{\mathrm{GOS}}{ }^{*}$ & References \\
\hline Bullera singularis & $\beta$-galactosidase - Immobilized enzyme & $45^{\circ} \mathrm{C}-\mathrm{pH} 3.7-120$ hours - lactose $30 \%$ & $55 \%$ & Shin, Park, Yang (1998) \\
\hline Sulfolobus solfataricus & $\beta$-galactosidase - Free enzyme & $80^{\circ} \mathrm{C}-\mathrm{pH} 6.0-6$ hours - lactose $40 \%$ & $12.5 \%$ & Kim et al. (2006) \\
\hline Bifidobacterium infantis & $\beta$-galactosidase - Whole cells & $50^{\circ} \mathrm{C}-6$ hours - lactose $40 \%$ & $33 \%$ & Roy, Daoudi, Azaola (2002) \\
\hline Aspergillus orysae & $\beta$-galactosidase - Immobilized enzyme & $40^{\circ} \mathrm{C}-\mathrm{pH} 4.0-2$ hours - lactose $20 \%$ & $17.3 \%$ & Gaur et al. (2006) \\
\hline Penicillium simplicissimum & $\beta$-galactosidase - Free enzyme & $50^{\circ} \mathrm{C}-\mathrm{pH} 6.5-8$ hours - lactose $60 \%$ & $30.5 \%$ & Cruz et al. (1999) \\
\hline Sterigmatomyces elviae & $\beta$-galactosidase - Free enzyme & $60^{\circ} \mathrm{C}-\mathrm{pH} 5.0-50$ hours - lactose $20 \%$ & $39 \%$ & Onishi and Tanaka, (1995) \\
\hline Aspergillus orysae & $\beta$-galactosidase - Immobilized enzyme & $40^{\circ} \mathrm{C}-\mathrm{pH} 4.5-4$ hours - lactose $50 \%$ & $27 \%$ & Albayrak and Yang, (2002) \\
\hline
\end{tabular}


also formed (LÓPEZ-LEIVA; GUZMAN, 1995). Thus, the low market value for lactose due to its oversupply has stimulated GOS manufacture from whey lactose. Some studies have used whey lactose solution in several concentrations (around 20\% $\mathrm{w} / \mathrm{v}$ ) as the reaction media to GOS synthesis. Employing a $\beta$-galactosidase from Kluyveromyces fragilis and an initial whey lactose content of 20 and $14 \% \mathrm{w} / \mathrm{w}$, the maximum yield of GOS reached 31\% w/w (FODA; LÓPEZ-LEIVA, 2000) and around $23 \%$ w/w (RUSTOM; FODA; LÓPEZ-LEIVA, 1998), respectively. In another report, a GOS yield of $34 \% \mathrm{w} / \mathrm{w}$ by $\beta$-galactosidase from Bullera singularis was found starting from $20 \% \mathrm{w} / \mathrm{v}$ cheese whey (CHO et al., 2003). These are impressive results since the GOS yields with purified lactose is usually within the range of 26 to $41 \% \mathrm{w} / \mathrm{w}$ when an initial substrate content of 20 to $50 \%$ is employed (CHO et al., 2003; NERI et al., 2009; SHEU et al., 1998). Therefore, it is suggested that by-products from dairy factories have a great potential to be employed in industrial processes for oligosaccharides production, although refined studies on scale up processes are still required.

An excellent alternative to reduce costs of NDO production is the use of low cost culture media, such as agro-industrial wastes rich in carbohydrates. There are several reports of by-products used to produce the enzyme either by Solid State Fermentation (SANGEETHA; RAMESH; PRAPULLA, 2004b; PARK; PASTORE, 2006) or submerged fermentation (DORTA et al., 2006) and to produce the oligosaccharides themselves (GHAZI et al., 2006; SHIN et al., 2004). The production of enzymes in residue media could be more feasible at the industrial level than NDO production in these media because, in the latter case, more elaborate downstream processes are required, increasing purification costs.

\section{Conclusion}

Traditional chemical processes are gradually being replaced by bioprocesses for the production of different substances. The tendency is for many ingredients to be produced using biotechnological tools, with the advantage of producing, under mild conditions and with lower environmental impact, enantiomerically pure compounds which may be labeled "natural". However, the high production costs involved in this kind of process is yet one of the major drawbacks for its wide adoption. One of the alternatives to overcome this scenario is the use of industrial residues as culture medium for microorganisms. Based on this review, which showed an increasing adoption of this technique, it seems that this approach will guide the biotechnology industry in the future, representing not only a noble destination for the residues but also a reduction in the manufacturing costs of bioproducts.

\section{References}

ADAMS, A.; DEMYTTENAERE, J. C. R.; DE KIMPE, N. Biotransformation of (R)-(+)- and (S)-(-)-limonene to Alphaterpineol by Penicillium digitatum - Investigation of the Culture Conditions. Food Chemistry, v. 80, n. 4, p. 525-534, 2003.

ALBAYRAK, N.; YANG, S. T. Production of Galacto-Oligosaccharides from Lactose by Aspergillus oryzae $\beta$-Galactosidase Immobilized in Cotton Cloth. Biotechnology and Bioengineering, v. 77, n. 1, p. 8-19, 2002.

ARMSTRONG, D. W.; MARTIN, S. M.; YAMAZAKI, H. Production of ethyl acetate from dilute ethanol solutions by Candida utilis. Biotechnology and Bioengineering, v. 26, n. 9, p. 1038-1041, 1984.

ASLAN, Y.; TANRISEVEN, A. Immobilization of Pectinex Ultra SP-L to produce galactooligosaccharides. Journal of Molecular Catalysis B: Enzymatic, v. 45, p. 73-77, 2007.

ASSAF, S.; HADAR, Y.; DOSORETZ, C. G. 1-Octen-3-ol and 13-hydroperoxylinoleate are products of distinct pathways in the oxidative breakdown of linoleic acid by Pleurotus pulmonarius. Enzyme and Microbial Technology, v. 21, n. 7, p. 484-490, 1997.

BAUER, K.; GARBE, D.; SURBURG, H. Common Fragrance and Flavor Materials: Preparation, Properties and Uses. 4th ed. Weinheim: Wiley - VCH, 2001.293 p.

BERGER, R. G. Biotechnology of flavours - the next generation. Biotechnology Letters, v. 31, n. 11, 2009.

BICAS, J. L. et al. Integrated process for co-production of alkaline lipase and R-(+)- $\alpha$-terpineol by Fusarium oxysporum. Food Chemistry, v. 120 , n. 2, p. 452-456, 2010.

BICAS, J. L. et al. Optimization of R-(+)- $\alpha$-terpineol Production by the Biotransformation of R-(+)-Limonene. Journal of Industrial Microbiology and Biotechnology, v. 35, n. 9, p. 1061-1070, 2008a.

BICAS, J. L. et al. A bioprocess for the production of high concentrations of R-(+)- $\alpha$-terpineol from R-(+)-limonene. Process Biochemistry. In press. DOI:10.1016/j.procbio.2009.11.007.

BICAS, J. L. et al. Characterization of Monoterpene Biotransformation in Two Pseudomonads. Journal of Applied Microbiology, v. 105, p. 1991-2001, 2008b.

BICAS, J. L.; DIONISIO, A. P.; PASTORE, G. M. Bio-oxidation of terpenes: an approach to Flavor industry. Chemical Reviews, v. 109, n. 9, p. 4518-4531, 2009

BLUEMKE, W.; SCHRADERB, J. Integrated bioprocess for enhanced production of natural flavors and fragrances by Ceratocystis moniliformis. Biomolecular Engineering, v. 17, n. 4-5, p. 137-142, 2001.

BRAMORSKI, A. et al. Production of volatile compounds by the edible fungus Rhizopus oryzae during solid-state cultivation on tropical agro-industrial substrates. Biotechnology Letters, v. 20, n. 4, p. 359-362, 1998a.

BRAMORSKI, A. et al. Fruit aroma production by Ceratocystis fimbriata in static cultures from solid agro-industrial wastes. Revista de Microbiologia, v. 28, n. 3, p. 208-212, 1998 b.

CADWALLADER, K. R. et al. Bioconversion of (+)-Limonene by Pseudomonas gladioli. Journal of Food Science, v. 54, n. 5, p. 1241-1245, 1989.

CADWALLADER, K. R.; BRADDOCK, R. J.; PARISH, M. E. Isolation of $\alpha$-Terpineol Dehydratase from Pseudomonas gladioli. Journal of Food Science, v. 57, n. 1, p. 241-244, 248, 1992.

CHAMBERT, R.; GONZY-TRÉBOUL, G. Levansucrase of Bacillus subtilis: Kinetic and Thermodynamic Aspects of Transfructosylation Processes. European Journal of Biochemistry, v. 62, p. 55-64, 1976.

CHAMBERT, R.; TREBOUL, G.; DEDONDER, R. Kinetic Studies of Levansucrase of Bacillus subtilis. European Journal of Biochemistry, v. 41, p. 285-300, 1974. 
CHO, Y. J.; SHIN, H. J.; BUCKE, C. Purification and biochemical properties of a galactooligosaccharide producing $\beta$-Galactosidase from Bullera singularis. Biotechnology Letters, v. 25, n. 24, p. 2107-2111, 2003.

CHOCKCHAISAWASDEE, S. et al. Synthesis of Galacto-oligosaccharide From Lactose Using $\beta$-Galactosidase From Kluyveromyces lactis: Studies on Batch and Continuous UF Membrane-Fitted Bioreactors. Biotechnology and Bioengineering, v. 89, n. 4, p. 434-443, 2004.

CHRISTEN, P. et al. Caracterization of volatile compounds produced by Rhyzopus strains grown on agro-industrial solid wastes. Bioresource Technology, v. 71, n. 3, p. 211-215, 2000.

CHRISTEN, P.; MEZA, J. C.; REVAH, S. Fruity aroma production in solid state fermentation by Ceratocystis fimbriata: influence of the substrate type and the presence of precursors. Mycological Research, v. 101, n. 8. p. 911-919, 1997.

COLLINS, R. P.; HALIM, A. F. Essential oil composition of Ceratocystis virescens. Mycologia, v. 69, n. 6, p. 1129-1136, 1977.

The National Research Council. Committee on Bioprocess Engineering. Putting biotechnology to work: bioprocess engineering. Wasington, D.C.: National Academy of Sciences, 1992. 120 p.

CRITTENDEN, R. G. Prebiotics. In: TANNOCK, G. W. (Ed.). Probiotics: a critical review. Wymondham: Horizon Scientific Press, 1999. p. 141-156.

CROWELL, P. Prevention and therapy of cancer by dietary monoterpenes. Journal of Nutrition, v. 129, n. 3, p. 775S-778S, 1999.

CRUZ, R. et al. Production of fructooligosaccharides by the mycelia of Aspergillus japonicus immobilized in calcium alginate. Bioresource Technology, v. 65, n. 1-2, p. 139-143, 1998.

CRUZ, R. et al. Production of transgalactosylated oligosaccharides (TOS) by galactosyltransferase activity from Penicillium simplicissimum. Bioresource Technology, v. 70, p. 165-171, 1999.

CUMMINGS, J. H. et al. A new look at dietary carbohydrate: chemistry, physiology and health. European Journal of Clinical Nutrition, v. 51, n. 7, p. 417-423, 1997.

DAMASCENO, S. et al. Production of volatile compounds by Geotrichum fragrans using cassava wastewater as substrate. Process Biochemistry, v. 39, n. 4, p. 411-414, 2003.

DAUGSCH, A.; PASTORE, G. M. Obtenção de vanilina: oportunidade biotecnológica. Química Nova, v. 28, n. 4, p. 642-645, 2005.

DE CARVAlHO, C. C. C. R.; DA FONSECA, M. M. R. Carvone: Why and how should one bother to produce this terpene. Food Chemistry, v. 95, n. 3, p. 413-422, 2006.

DELZENNE, N. M. Oligosaccharides: state of the art. Proceedings of the Nutrition Society, v. 62, n. 1, p. 177-182, 2003.

DEMAIN, A. L.; JACKSON, M.; TRENNER, N. R. Thiamine-dependent Accumulation of Tetramethylpyrazine Accompanying a Mutation in the Isoleucine-Valine Pathway. Journal of Bacteriology, v. 94, n. 2, p. 323-326, 1967.

DEMYTTENAERE, J. C. R. Biotransformation of Terpenoids by Microorganisms. In: RAHMAN, A. (Ed.). Studies in Natural Products Chemistry. London: Elsevier, 2001. p. 125-178.

DEMYTTENAERE, J. C. R.; VAN BELLEGHEM, K.; DE KIMPE, N. Biotransformation of (R)-(+)- and (S)-(-)-Limonene by Fungi and the Use of Solid Phase Microextraction for Screening. Phytochemistry, v. 57, n. 2, p. 199-208, 2001.

DI GIOIA, D. et al. Production of biovanillin from wheat bran. Enzyme and Microbial Technology, v. 41, n. 4, p. 498-505, 2007.
DOBLE, M.; KRUTHIVENTI, A. K.; GAIKAR, V. G. Biotransformation and Bioprocesses. New York: Marcel Dekker Inc., 2004.

DORTA, C. et al. Sugarcane molasses and yeast powder used in the Fructooligosaccharides production by Aspergillus japonicus-FCL $119 \mathrm{~T}$ and Aspergillus niger ATCC 20611. Journal of Industrial Microbiology and Biotechnology, v. 33, n. 12, p. 1003-1009, 2006.

FERNÁNDEZ, R. C. et al. Production of fructooligosccharides by $\beta$-frutofuranosidase from Aspergillus sp. 27H. Journal of Chemical Technology and Biotechnology, v. 79, p. 268-272, 2004.

FODA, M. I.; LÓPEZ-LEIVA, M. Continuous production of oligosaccharides from whey using a membrane reactor. Process Biochemistry, v. 35, n. 6, p. 581-587, 2000.

FRANCKE, W.; BRUMMER, G. Terpene aus Ascoidea hylecoeti. Planta Medica, v. 34, p. 426-429, 1978.

FRANCO, M. R. B. Aroma e Sabor dos Alimentos: Temas Atuais. São Paulo: Livraria Varela, 2004. 246 p.

GATFIELD, I. L. Production of flavor and aroma compounds by biotechnology. Food technology, v. 42, n. 10, p. 110-169, 1988.

GAUR, R. et al. Galacto-oligosaccharide synthesis by immobilized Aspergillus oryzae $\beta$-galactosidase. Food Chemistry, v. 97, n. 3, p. 426-430, 2006.

GHAZI, I. et al. Beet sugar syrup and molasses as low-cost feedstock for the enzymatic production of fructo-oligosaccharides. Journal of Agricultural and Food Chemistry, v. 54, n. 8, p. 2964-2968, 2006.

GOUlAS, A.; TZORTZIS, G.; GIBSON, G. R. Development of a process for the production and purification of $\alpha$ - and $\beta$-galactooligosaccharides from Bifidobacterium bifidum NCIMB 41171. International Dairy Journal, v. 17, p. 648-656, 2007.

HARTEMINK, R.; VANLAERE, K. M. J.; ROMBOUTS, F. M. Growth of enterobacteria on fructo-oligosaccharides. Journal of Applied Microbiology, v. 83, n. 3, p. 367-374, 1997.

HAYASHI, S.; YOSHIYAMA, T.; FUJII, N. Production of a novel syrup containing neofructo-oligosaccharides by the cells of Penicillium citrinum. Biotechnology Letters, v. 22, n. 18, p. 1465-1469, 2000.

HetTWER, U.; GROSS, M.; RUDOLPH, K. Purification and Characterization of an Extracellular Levansucrase from Pseudomonas syringae pv. phaseolicola. Journal of Bacteriology, v. 177, n. 10, p. 2834-2839, 1995.

HÖLKER, U.; LENZ, J. Solid-state fermentation - are there any biotechnological advantages? Current Opinion in Microbiology, v. 8, n. 3, p. 301-306, 2005.

HUBBALL, J. A.; COLLINDS, R. P. A study of factor affecting the synthesis of terpenes by ceratocystis variospora. Mycologia, v. 70, n. 1, p. 117-29, 1978.

JANSSENS, L. et al. Production of flavours by microorganisms. Process Biochemistry, v. 27, n. 4, p. 195-215, 1992.

KAUFHOLD, J.; HAMMON, H. M.; BLUM, J. W. Fructooligosaccharide supplementation: effects on metabolic, endocrine and hematological traits in veal calves. Journal of Veterinary Medicine, Animal Physiology, Pathology and Clinical Medicine, v. 47, n. 1, p. 17-29, 2000.

KIM, B. W.; KWON, H. J.; PARK, H. Y. Production of a novel transfructosylating enzyme from Bacillus macerans EG-6. Bioprocess Engineering, v. 23, n. 1, p. 11-16, 2000.

KIM, S. K.; RAJAPAKSE, N. Enzymatic production and biological activities of chitosan oligosaccharides (COS): a review. Carbohydrates Polymers, v. 62, n. 4, p. 357-368, 2005. 
KIM, Y. S.; PARK, C. S.; OH, D. K. Lactulose production from lactose and fructose by a thermostable $\beta$-galactosidase from Sulfolobus solfataricus. Enzyme and Microbial Technology, v. 39, p. 903-908, 2006.

KOSUGE, T.; KAMIYA, H. Discovery of a Pyrazine in a Natural Product: Tetramethylpyrazine from Cultures of a Strain of Bacillus subtilis. Nature, v. 193, n. 4817, p. 776, 1962.

KRAIDMAN, G.; MUKHERJEE, B. B.; HILL, J. D. Conversion of D-Limonene into an Optically Active Isomer of $\alpha$-Terpineol by a Cladosporium Species. Bacteriological Proceedings, v. 69, p. 63, 1969.

LANZA, E.; KO, K. H.; PALMER, J. K. Aroma production by cultures of Ceratocystis moniliformis. Journal of agricultural and food chemistry, v. 24, n. 6, p. 1247-1250, 1976.

LASETER, J. L.; WEETE, J. D.; WALKINSHAW, C. H. Volatile terpenoids from aeciospores of Cronartium fusiforme. Phytochemistry, v. 12, p. 387-390, 1973.

LESAGE-MEESSEN, L. et al. Biotechnological process involving filamentous fungi to produce natural crystalline vanillin from maize bran. Applied Biochemistry and Biotechnology, v. 102-103, n. 1-6, p. 141-153, 2002.

LIM, J. S. et al. Studies on production and physical properties of neoFOS produced by co-immobilized Penicillium citrinum and neofructosyltransferase. European Food Research and Technology, v. 225, n. 3-4, p. 457-462, 2007.

LONGO, M. A.; SANROMÁN, M. A. Production of food aroma compounds: microbial and enzymatic methodologies. Food Technological Biotechnological, v. 44, n. 3, p. 335-353, 2006.

LÓPEZ-LEIVA, M.; GUZMAN, M. Formation of oligosaccharides during enzymic hydrolysis of milk whey permeates. Process Biochemistry, v. 30, n. 8, p. 757-762, 1995.

MAALEJ-ACHOURI, I. et al. Production of xylo-oligosaccharides from agro-industrial residues using immobilized Talaromyces thermophilus xylanase. Journal of Molecular Catalysis B: Enzymatic, v. 59, n. 1-3, p. 145-152, 2009.

MAKKAR, R. S.; CAMEOTRA, S. S. An update on the use of unconventional substrates for biosurfactant production and their new applications. Applied Microbiololy Biotechnology, v. 58, n. 4, p. 428-434, 2002.

MARÓSTICA Jr., M. R.; PASTORE, G. M. Biotransformation of citronellol in rose-oxide using cassava wastewater as a medium. Ciência e Tecnologia de Alimentos, v. 26, n. 3, p. 690-696, 2006.

MARÓSTICA Jr., M. R.; PASTORE, G. M. Production of R-(+)a-terpineol by the biotransformation of limonene from orange essential oil, using cassava waste water as medium. Food Chemistry, v. 101, n. 1, p. 345-350, 2007b.

MARÓSTICA Jr., M. R. et al. Fungal biotransformation of monoterpenes found in agro-industrial residues from orange and pulp industries into aroma compounds: Screening using solid phase microextraction. Food Science and Biotechnology, v. 16, n. 1, p. 37-42, 2007.

MARÓSTICA Jr., M. R.; PASTORE, G. M. Biotransformation of Limonene: a Review of the Main Metabolic Pathways. Química Nova, v. 30, n. 2, p. 382-387, 2007a.

MARQUES, D. B.; PASTORE, G. M. Produção de aromas naturais por microrganismos. Boletim SBCTA, v. 33, n. 1, p. 80-85, 1999.

MARTÍNEZ-FLEITES, C.; ORTÍZ-LOMBARDÍA, M.; PONS, T. Crystal structure of levansucrase from the Gram-negative bacterium Gluconacetobacter diazotrophicus. The Biochemical Journal, v. 390, n. 1, p. 19-27, 2005.
MATSUMOTO, K.; KOBAYASHI, Y.; TAMURA N. Production of Galactooligosaccharides with $\beta$-Galactosidase. Denpun Kagaku, v. 36, p. 123-130, 1989.

MEDEIROS, A. B. P. et al. Optimization of the production of aroma compounds by Kluyveromyces marxianus in solid-state fermentation using factorial design and response surface methodology. Biochemical Engineering Journal, v. 6, n. 1, p. 33-39, 2000.

MOLIS, C. et al. Digestion, excretion, and energy value of fructooligosaccharides in healthy humans. The American Journal of Clinical Nutrition, v. 64, n. 3, p. 324-328, 1996.

MONSAN, P.; PAUL, F. Enzymatic synthesis of oligosaccharides. FEMS Microbiology Reviews, v. 16, n. 2-3, p. 187-192, 1995.

MUHEIM, A. et al. Microbiological process for producing vanillin. United States Patent 6,235,507. May 22th, 2001.

MUSSATO, S. I.; AGUILAR, C. N.; RODRIGUES, L. R. Fructooligosaccharides and $\beta$-fructofuranosidase production by Aspergillus japonicus immobilized on lignocellulosic materials. Journal of Molecular Catalysis B: Enzymatic, v. 59, n. 1-3, p. 76-81, 2009.

NERI, D. F. M. et al. Galacto-oligosaccharides production during lactose hydrolysis by free Aspergillus oryzae $\beta$-galactosidase and immobilized on magnetic polysiloxane-polyvinyl alcohol. Food Chemistry, v. 115, n. 1, p. 92-99, 2009.

ONISHI, N.; TANAKA, T. Purification and Properties of a Novel Thermostable Galacto-Oligosaccharide-Producing $\beta$-Galactosidase from Sterigmatomyces elviae CBS8119. Applied and Environmental Microbiology, v. 61, n. 11, p. 4026-4030, 1995.

ORZUA, M. C. et al. Exploitation of agro industrial wastes as immobilization carrier for solid-state fermentation. Industrial Crops and Products, v. 30, n. 1, p. 24-27, 2009.

OZIMEK, L. K.; KRALJ, S.; VAN DER MAAREL, M. J. E. C. The levansucrase and inulosucrase enzymes of Lactobacillus reuteri 121 catalyse processive and non-processive transglycosylation reactions. Microbiology, v. 152, n. 4, p. 1187-1196, 2006.

PANDEY, A. Solid-state fermentation. Biochemical Engineering Journal, v. 13, n. 2-3, p. 81-84, 2003.

PANDEY, A. et al. New developments in solid state fermentation: I-bioprocesses and products. Process Biochemistry, v. 35, n. 10, p. 1153-1169, 2000b.

PANDEY, A. et al. Biotechnological potential of agro-industrial residues. II: cassava bagasse. Bioresource Technology, v. 74, n. 1, p. 81-87, 2000a.

PANDEY, A. et al. Biotechnological potential of coffee pulp and coffee husk for bioprocesses. Biochemical Engineering Journal, v. 6, n. 2, p. $153-162,2000 \mathrm{c}$.

PANDEY, A. et al. Biotechnological potential of agro-industrial residues. I: sugarcane bagasse. Bioresource Technology, v. 74, n. 1, p. 69-80, 2000d.

PARK, Y. K.; ALMEIDA, M. M. Production of fructooligosaccharides from sucrose by a transfructosylase from Aspergillus niger. World Journal of Microbiology and Biotechnology, v. 7, n. 3, p. 331-334, 1991.

PARK, Y. K.; PASTORE, G. M. Process for preparing betafructofuranosidase enzyme and a process for producing fructooligosaccharides. United States Patent 7,063,976. June 20th, 2006.

PARK, Y. C.; SHAFFER, C. E. H.; BENNETT, G. N. Microbial formation of esters. Applied Microbiology and Biotechnology, v. 85, n. 1, 2009. 
PASTORE, G. M.; PARK, Y. K.; MIN, D. B. Production of fruity aroma by Neurospora from beiju. Mycological Research, v. 98, n. 11, p. 1300-1302, 1994.

PASTORE, G. M.; PARK, Y. K.; MIN, D. B. Production of fruity aroma by Neurospora species isolated from Beiju. Revista de Microbiologia, v. 26, n. 1, p. 55-58, 1995.

PESCHECK, M. et al. Improved monoterpene biotransformation with Penicillium sp. by use of a closed gas loop bioreactor. Journal of Industrial Microbiology and Biotechnology, v. 36, n. 6, p. 827-836, 2009.

PRENOSIL, J. E.; STUCKER, E.; BOURNE, J. R. Formation of oligosaccharides during enzymatic lactose hydrolysis and their importance in a whey hydrolysis process: Part II: Experimental. Biotecnology and Bioengineering, v. 30, n. 9, p. 1019-1025, 1987.

RABENHORST, J.; HOPP, R. Process for the preparation of vanillin and microorganisms suitable therefore. United States Patent 6,133,003. October 17th, 2000.

ROBERFROID, M. B.; SLAVIN, J. Non digestible oligosaccharides. Critical Reviews in Food Science and Nutrition, v. 40, n. 60, p. 461-480, 2000.

ROSSI, S. C. et al. Improving fruity aroma production by fungi in SSF using citric pulp. Food Research International, v. 42, n. 4, p. 484-486, 2009.

ROY, D.; DAOUDI, L.; AZAOLA, A. Optimization of galactooligosaccharide production by Bifidobacterium infantis RW-8120 using response surface methodology. Journal of Industrial Microbiology and Biotechnology, v. 29, p. 281-285, 2002.

RUSTOM, I. Y. S.; FODA, M. I.; LÓPEZ-LEIVA, M. H. Formation of oligosaccharides from whey UF-permeate by enzymatic hydrolysis analysis of factors. Food Chemistry, v. 62, n. 2, p. 141-147, 1998.

SAKO, T.; MATSUMOTO, K.; TANAKA, R. Recent progress on research and applications of non-digestible galacto-oligosaccharides. International Dairy Journal, v. 9, n. 1, p. 69-80, 1999.

SANGEETHA, P. T.; RAMESH, M. N.; PRAPUllA, S. G. Fructooligosaccharide production using fructosyl transferase obtained from recycling culture of Aspergillus oryzae CFR 202. Process Biochemistry, v. 40, n. 3-4, p. 1085-1088, 2005a.

SANGEETHA, P. T.; RAMESH, M. N.; PRAPULLA, S. G. Production of fructo-oligosaccharides by fructosyl transferase from Aspergillus oryzae CFR 202 and Aureobasidium pullulans CFR 77. Process Biochemistry, v. 39, n. 6, p. 755-760, 2004a.

SANGEETHA, P. T.; RAMESH, M. N.; PRAPULLA, S. G. Production of fructosyl transferase by Aspergillus oryzae CRF 202 in solid-state fermentation using agricultural by-products. Applied Microbiology and Biotechnology, v. 65, p. 530-537, 2004b.

SANGEETHA, P. T.; RAMESH, M. N.; PRAPULLA, S. G. Recent trends in microbial production, analysis and application of Fructooligosaccharides. Food Science and Technology, v. 16, n. 10, p. 442-457, 2005b.

SANTOS, A. M. P.; MAUGERI, F. Synthesis of fructooligosaccharides from sucrose using inulinase from Klyveromyces marxianus. Food Technology and Biotechnology, v. 45, n. 2, p. 181-186, 2007.

SAVITHIRY, N.; CHEONG, T. K.; ORIEL, P. Production of Alpha-Terpienol from Escherichia coli Cells Expressing Thermostable Limonene Hydratase. Applied Biochemistry and Biotechnology, v. 63, p. 213-220, 1997.

SHEU, D. C. et al. Production of galactooligosaccharides by $\beta$-galactosidase immobilized on glutaraldehyde-treated chitosan beads. Biotechnology Techniques, v. 12, n. 4, p. 273-276, 1998.
SHIN, H. J.; PARK, J. M.; YANG, J. W. Continuous production of galactooligosaccharides from lactose by Bullera singularis $\beta$-galactosidase immobilized in chitosan beads. Process Biochemistry, v. 33, n. 8, p. 787-792, 1998.

SHIN, H. T. et al. Production of fructo-oligosaccharides from molasses by Aureobasidium pullulans cells. Bioresource Technology, v. 93, n. 1, p. 59-62, 2004.

SINGHANIA, R. R. et al. Recent advances in solid-state fermentation. Biochemical Engineering Journal, v. 44, n. 1, p. 13-18, 2009.

SLOAN, A. E. The top 10 functional food trends: the next generation. Food Technology, v. 56, n. 4, p. 32-35, 2002.

SOARES, M.; CHRISTEN, P; PANDEY, A. Fruit flavor production by Ceratocystis fimbriata grown on coffe husk in solid-state fermentation. Process Biochemistry, v. 35, p. 857-861, 2000.

SONG, D. D.; JACQUES, N. A. Purification and enzymic properties of the fructosyltransferase of Streptococcus salivarius ATCC 25975. The Biochemical Journal, v. 341, n. 2, p. 285-291, 1999.

SPIEGEL, J. E.; ROSE, R.; KARABELL, P. Safety and benefits of frutooligosaccharides as food ingredients. Food Technology, v. 48, n. 1, p. 85-89, 1994.

TÁMBARA, Y.; HORMAZA, J. V.; PÉREZ, C. Structural analysis and optimized production of fructo-oligosaccharides by levansucrase from Acetobacter diazotrophicus STR4. Biotechnology Letters, v. 21, p. 117-121, 1999.

TAN, Q.; DAY, D. F. Bioconversion of Limonene to $a$-Terpineol by Immobilized Penicillium digitatum. Applied Microbiology and Biotechnology, v. 49, n. 1, p. 96-101, 1998a.

TAN, Q.; DAY, D. F. Organic Co-solvent Effects on the Bioconversion of (R)-(+)-Limonene to (R)-(+)- $a$-Terpineol. Process Biochemistry, v. 33, n. 7, p. 755-761, 1998b.

TAN, Q.; DAY, D. F.; CADWALLADER, K. R. Bioconversion of (R)-(+)-Limonene by P. digitatum (NRRL 1202). Process Biochemistry, v. 33, n. 1, p. 29-37, 1998c.

THIBAULT, J. F. et al. Fungal bioconversion of agricultural by-products to vanillin. Lebensmittel-Wissenschaft und-Technologie, v. 31, n. 6, p. 530-536, 1998.

TOMOMATSU, H. Health effects of oligosaccharides. Food Technology, v. 48, n. 10, p. 61-65, 1994.

TORRES, B. R. et al. Vanillin bioproduction from alkaline hydrolyzate of corn cob by Escherichia coli JM109/pBB1. Enzyme and Microbial Technology, v. 44, n. 3, p. 154-158, 2009.

VAN HIJUM, S. A. F. T.; SZALOWSKA, E.; VAN DER MAAREL, M. J. E. C. Biochemical and molecular characterization of a levansucrase from Lactobacillus reuteri. Microbiology, v. 150, n. 3, p. 621-630, 2004.

WALTON, N. J. et al. Novel approaches to the biosynthesis of vanillin. Current Opinion in Biotechnology, v. 11, n. 5, p. 490-496, 2000.

WANG, L.; YANG, S. T. Solid State Fermentation and its applications. In: YANG, S. T. (Ed.). Bioprocessing for value-added products from renewable resources. Amsterdam: Elsevier, 2007. p. 465-489.

WELSH, F. W., MURRAY, W. D., WILLIAMS, R. E. Microbiological and enzymatic production of flavor and fragrance chemicals. Critical Reviews in Biotechnology, v. 9, n. 2, p. 105-169, 1989.

YAMASHITA, K.; KAWAI, K.; ITAKAMURA, M. Effects of fructooligosaccharides on blood-glucose and serum lipids in diabetic subjects. Nutrition Research, v. 4, n. 6, p. 961-966, 1984.

YAMAUCH, H. et al. Production of characteristic odors by Neurospora. Agricultural and Biological Chemistry, v. 55, n. 12, p. 3115-3116, 1991.

YAMAUCHI, H.; HASUO, T.; AMACHI, T. Purification and Characterization of Acyl Coenzyme A: Alcohol Acyltransferase of Neurospora sp. Agricultural and Biological Chemistry, v. 53, n. 6, p. 1551-1556, 1989. 
YOSHIZAWA, K. et al. Production of a fruity odor by Neurospora sp. Agricultural and Biological Chemistry, v. 52, n. 8, p. 2129-2130, 1988.

YUN, J. W. Fructooligosaccharides - Ocurrence, preparation and application. Enzyme and Microbial Technology, v. 19, n. 2, p. 107-117, 1996.
YUN, J. W.; SONG, S. K. The production of high-content fructooligosaccharides from sucrose by the mixed-enzyme system of fructosyltranferase and glucose oxidase. Biotechnology Letters, v. 15, n. 6, p. 573-576, 1993.

ZHENG, L. et al. Production of vanillin from waste residue of rice bran oil by Aspergillus niger and Pycnoporus cinnabarinus. Bioresource Technology, v. 98, n. 5, p. 1115-1119, 2007. 